\title{
Host plant use drives genetic differentiation in syntopic populations of Maculinea alcon
}

András Tartally, Andreas Kelager, Matthias A Fürst, David R Nash

The rare socially parasitic butterfly Maculinea alcon occurs in two forms, which are characteristic of hygric or xeric habitats, and which exploit different host plants and host ants. The status of these two forms has been the subject of considerable controversy. Populations of the two forms are usually spatially distinct, but at Răscruci in Romania both forms occur on the same site (syntopically). We examined the genetic differentiation between the two forms using eight microsatellite markers, and compared with a nearby hygric site, Şardu. Our results showed that while the two forms are strongly differentiated at Răscruci, it is the xeric form there that is most similar to the hygric form at Şardu, and Bayesian clustering algorithms suggest that these two populations have exchanged genes relatively recently. We found strong evidence for population substructuring, caused by high within host ant nest relatedness, indicating very limited dispersal of most ovipositing females, but not association with particular host ant species. Our results are consistent with the results of larger scale phylogeographic studies that suggest that the two forms represent local ecotypes specialising on different host plants, each with a distinct flowering phenology, providing a temporal rather than spatial barrier to gene flow. 


\section{Host plant use drives genetic differentiation in syntopic populations of}

\section{Maculinea alcon}

3

4 Authors

5 András Tartally ${ }^{1,2^{*}}$, Andreas Kelager ${ }^{2,3 *}$, Matthias A. Fürst ${ }^{2,4}$, David R. Nash ${ }^{2 \dagger}$.

7 Affiliations

8 1. University of Debrecen, Department of Evolutionary Zoology and Human Biology,

9 Hungary, H-4032, Debrecen, Egyetem tér 1.

10 2. Centre for Social Evolution, Department of Biology, University of Copenhagen.

11 Universitetsparken 15, DK-2100 Copenhagen, Denmark.

12 3. Center for Macroecology, Evolution and Climate, Natural History Museum of Denmark,

13 University of Copenhagen. Universitetsparken 15, DK-2100 Copenhagen, Denmark.

14 4. IST Austria (Institute of Science and Technology Austria), Am Campus 1, 3400 Klosterneuburg, Austria.

$17 *$ These authors contributed equally to this work

$18 \dagger$ Corresponding author. E-mail: DRNash@bio.ku.dk

Tel: +4535321323

Fax: +4535321250 


\section{Abstract}

24 The rare socially parasitic butterfly Maculinea alcon occurs in two forms, which are

25 characteristic of hygric or xeric habitats, and which exploit different host plants and host ants.

26 The status of these two forms has been the subject of considerable controversy. Populations of

27 the two forms are usually spatially distinct, but at Răscruci in Romania both forms occur on the

28 same site (syntopically). We examined the genetic differentiation between the two forms using

29 eight microsatellite markers, and compared with a nearby hygric site, Şardu. Our results showed

30 that while the two forms are strongly differentiated at Răscruci, it is the xeric form there that is

31 most similar to the hygric form at Şardu, and Bayesian clustering algorithms suggest that these

32 two populations have exchanged genes relatively recently. We found strong evidence for

33 population substructuring, caused by high within host ant nest relatedness, indicating very

34 limited dispersal of most ovipositing females, but not association with particular host ant species.

35 Our results are consistent with the results of larger scale phylogeographic studies that suggest

36 that the two forms represent local ecotypes specialising on different host plants, each with a

37 distinct flowering phenology, providing a temporal rather than spatial barrier to gene flow. 
40 Larvae of Maculinea van Eecke (Lepidoptera: Lycaenidae) butterflies start their development on

41 specific host plants. A few weeks later they are adopted into the nests of suitable Myrmica 42 Latreille (Hymenoptera: Formicidae) colonies, where they act as social parasites of the ants 43 (Thomas et al., 1989). This unusual life cycle has shaped their evolution, as different populations 44 are strongly selected to adapt to different initial host plants and Myrmica species depending on 45 their availability (Thomas et al., 1989; Witek et al., 2008).

46 Larvae of the Maculinea alcon Denis \& Schiffermüller group follow a rather specialised 47 development compared to other Maculinea species, as they are not simply predators of ant brood, 48 but are fed by Myrmica workers in preference to their own brood - a behaviour that has been 49 described as a "cuckoo" strategy (Thomas \& Elmes, 1998). Because they are constantly 50 interacting with worker ants, this means that they need to adapt precisely to the local host ant 51 species, e.g. by mimicking the odour (Akino et al., 1999; Nash et al., 2008; Thomas \& Settele, 52 2004) and sounds (Barbero et al., 2009) of the ants, in order to be accepted by a suitable Myrmica colony. While the initial host plants of this group are all species of gentian (Gentiana L. and Gentianella Mönch), they can occur in very different open habitats, such as lowland and mountain meadows or wet and dry swards (Munguira \& Martín, 1999; Oostermeijer, Vantveer \& Dennijs, 1994; Settele, Kühn \& Thomas, 2005; Tartally, Koschuh \& Varga, 2014). Based on

57 these different habitat types, several forms or (sub)species of the M. alcon group have been described. The most widely accepted separation within this group is that the nominotypic $M$. alcon occurs on humid meadows and there is another xerophilous form which has usually been referred to as M. rebeli Hirschke (Thomas et al., 2005; Thomas \& Settele, 2004; Wynhoff,

61 1998). Both forms are patchily distributed (Wynhoff, 1998) and have been considered as 
62 endangered in many European countries (Munguira \& Martin, 1999), with the xerophilous form

63 considered to be a European endemic (Munguira \& Martin, 1999). However, several papers

64 (Habeler, 2008; Kudrna \& Belicek, 2005; Kudrna \& Fric, 2013) have made the case that the

65 xerophilous form is most likely not synonymous with the nominotypic M. rebeli, which is found

66 at higher altitude, and has a unique host plant and host ant usage (Tartally, Koschuh \& Varga,

67 2014). Furthermore, recent molecular phylogenetic studies (Als et al., 2004; Ugelvig et al.,

68 2011b; Bereczki et al., 2015) suggest that the hygrophilous and xerophilous forms of M. alcon,

69 while distinct from other congeners, are not two distinct lineages, and show very little variation

70 in genes normally used for phylogenetic inference. This has been confirmed by several regional

71 population genetic studies (Bereczki et al., 2005; Bereczki, Pecsenye \& Varga, 2006; Sielezniew

72 et al., 2012; Bereczki et al., 2015), where there is no consistent separation of the two forms. This

73 has led to the current situation where xerophilous and hygrophilous $M$. alcon are not

74 distinguished for conservation purposes, and the species is now considered as "of least concern"

75 in Europe (Van Swaay et al., 2010). To avoid confusion, we will refer to the "typical"

76 hygrophilous form of $M$. alcon as ' $M$. alcon $H$ ' and the xerophilous form as ' $M$. alcon $X$ '

77 throughout the rest of this manuscript, following Tartally, Koschuh \& Varga (2014).

78 The host plant and host ant usage of the two M. alcon forms are different, because different

79 gentian and Myrmica species are available on the hygric sites of $M$. alcon $H$ and xeric sites of $M$.

80 alcon $X$. While $M$. alcon $H$ starts development typically on the marsh gentian (Gentiana

81 pneumonanthe L.), M. alcon $X$ typically uses the cross gentian (G. cruciata L.), and there is some

82 evidence that enzyme systems related to host plant use may be diverging in the two forms

83 (Bereczki et al., 2015). The development of M. alcon X typically continues in nests of Myrmica

84 schencki Viereck and My. sabuleti Meinert but M. alcon $H$ most often uses My. rubra L., My. 
85 ruginodis Nylander or My. scabrinodis Nylander as host ants. Furthermore, some other minor or

86 locally important host plant and host ant species have been recorded for both forms (summarized

87 in Witek, Barbero \& Markó, 2014).

88 Despite these differences in the host plant and ant usage of $M$. alcon $H$ and $M$. alcon $X$, 89 phylogenetic reconstruction using morphological and ecological characters suggests that western

90 Palaearctic $M$. alcon $H$ are closer to European $M$. alcon $X$ than Asian M. alcon $H$ (Pech et al., 91 2004). In combination, all these results suggest local ecological but not genetic differentiation of

92 the two forms between hygric and xeric sites. Until recently this could only be tested by 93 comparing sites that were separated by tens of kilometres or more, but in the last decade a site 94 has been recorded from Răscruci (Transylvanian basin, Romania) where patches supporting $M$. 95 alcon $H$ and $M$. alcon $X$ occur in a mosaic separated by tens of meters. The two forms use 96 different host plants and mostly different host ants on this site (Tartally et al., 2008), and their 97 flying periods are largely separated based on the phenology of their host plants (Czekes et al., 98 2014; Timuş et al., 2013). In addition, most previous genetic studies have been based on 99 collecting samples from either flying adults or caterpillars as they emerge from the host plant, 100 which means that any separation by host ant species could not be examined directly. Our aim 101 was therefore to investigate the genetic differentiation between the two forms of M. alcon at this 102 unique syntopic site, to relate this to differences in both host plant and host ant use, and to make 103 recommendations for the conservation of the forms based on their shared and predicted future 104 histories (c.f. Bowen \& Roman, 2005). 
106 Materials and Methods

107 Field methods

108 Two sites in Transylvania (Figure 1) were visited in the summers of 2007 and 2009 to record

109 host plant and host ant usage and to collect genetic samples of M. alcon. Host ant specificity

110 results from 2007 have already been published in Tartally et al. (2008). The first site is at

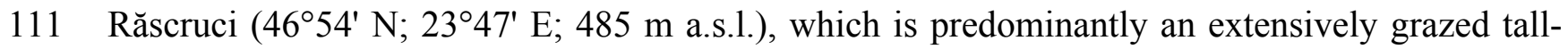

112 grass meadow steppe with Gentiana cruciata (the host plant of $M$. alcon X), but also with

113 numerous small marshy depressions with tall-forb vegetation in which G. pneumonanthe (the

114 host plant of $M$. alcon $H$ ) is common (Czekes et al., 2014). This site gave the unique possibility

115 to compare the host ant specificity and population genetics of $M$. alcon $H$ and $M$. alcon $X$ within

116 the same site. To collect samples, two nearby patches were chosen within this mosaic site where

117 G. pneumonanthe and G. cruciata were well separated from each other (there was a ca. $20 \mathrm{~m}$

118 wide zone without gentians). In other parts of this site border effects (because of the potential

119 migration of Myrmica colonies) or the co-occurrence of the two gentians made it difficult to find

120 M. alcon larvae originating clearly from $G$. pneumonanthe or $G$. cruciata. The patch with $G$.

121 pneumonanthe will henceforth be referred to as 'Răscruci wet' ( $M$. alcon $H$ patch), while the

122 patch with $G$. cruciata will be referred to as 'Răscruci dry' (M. alcon $X$ patch). The nearest

123 known $M$. alcon site (a $M$. alcon $H$ site) to Răscruci is at Şardu $\left(46^{\circ} 52^{\prime} \mathrm{N} ; 2^{\circ} 24^{\prime} \mathrm{E} ; 480 \mathrm{~m}\right.$

124 a.s.1.), $29 \mathrm{~km}$ west of Răscruci, which was chosen as a control site. Şardu is a tall-grass, tall-

125 sedge marshy meadow with locally dense stands of $G$. pneumonanthe. The two sites are

126 separated by a range of hills without suitable $M$. alcon habitat (Figure 1). 
127 To obtain data on the host ant specificity and to get samples for genetic analysis, Myrmica nests

128 were searched for within $2 \mathrm{~m}$ of randomly selected Gentiana host plants, which is considered to

129 be the approximate foraging zone of worker ants of the genus Myrmica (Elmes et al., 1998).

130 Searches were made no earlier than four weeks before the flying period of $M$. alcon at both sites,

131 so that any M. alcon caterpillars or pupae found must have survived the winter in the ant nest,

132 and hence have become fully integrated (Thomas et al., 2005). Nests were excavated carefully

133 but completely, after which the ground and vegetation were restored to as close to the original

134 conditions as possible. All M. alcon caterpillars, pupae and exuviae were counted, placed in 98\%

135 ethanol, and stored at $-20{ }^{\circ} \mathrm{C}$ until DNA could be extracted. Five to ten worker ants were also

136 collected from each ant nest and preserved in $70 \%$ ethanol for later identification in the

137 laboratory using keys by Seifert (1988) and Radchenko and Elmes (2010). For further details, see

138 Tartally et al. (2008).

140 Host ant specificity

141 Host ant specificity (deviation from random occurrence in nests of different Myrmica species)

142 was calculated based on the number of fully grown butterfly larvae, pupae and exuviae in two

143 ways: $P 1$ is the 2-tailed probability from a Fisher exact test of heterogeneity in infection of host

144 ant nests (as implemented at http://www.quantitativeskills.com/sisa/), and $P 2$ is the probability

145 from a randomization test of ant nests between species, using the software MACSAMP (Tartally et

146 al., 2008). Published (Tartally et al., 2008) and newly-collected data on host ant specificity were

147 combined for these analyses. In the case of Răscruci, host ant specificity results were calculated 
148 separately for Răscruci wet and Răscruci dry and also based on the combined data from both

149 patches ('Răscruci both’ below).

DNA extraction and microsatellite analysis

152 DNA was extracted from approximately $1-2 \mathrm{~mm}^{3}$ of tissue from caterpillars or pupae using a

$15310 \%$ Chelex-10mM TRIS solution with $5 \mu$ Proteinase K. Samples were incubated at $56^{\circ} \mathrm{C}$ for

154 minimum 3.5 hours or overnight and boiled at $99.9^{\circ} \mathrm{C}$ for $15 \mathrm{~min}$. The supernatant was collected

155 and stored at $5{ }^{\circ} \mathrm{C}$ or $-20^{\circ} \mathrm{C}$ for short or long term storage, respectively. For each sample, nine

156 polymorphic nuclear microsatellite loci developed for Maculinea alcon were amplified: Macu20,

157 Macu26, Macu28, Macu29, Macu30, Macu31, Macu40, Macu44, and Macu45 (Table 1; Ugelvig

158 et al., 2011a; Ugelvig et al., 2012) using a REDTaq ${ }^{\circledR}$ ReadyMix ${ }^{\text {TM }}$ PCR Reaction Mix (Sigma-

159 Aldrich). These primer pairs (see concentrations in table 1) were amplified using standard PCR

160 conditions: initial denaturation for $5 \mathrm{~min}$ at $95^{\circ} \mathrm{C}$ followed by 30 cycles of $30 \mathrm{~s}$ at $95{ }^{\circ} \mathrm{C}, 30 \mathrm{~s}$ at

161 locus-specific annealing temperature (see table 1) and $30 \mathrm{~s}$ extension at $72{ }^{\circ} \mathrm{C}$, finishing with

162 elongation of $15 \mathrm{~min}$ at $72{ }^{\circ} \mathrm{C}$ run on a Thermo PCR PXE 0.2 Thermal Cycler. Total reaction

163 volume was $10 \mu \mathrm{l}$ of which $1 \mu \mathrm{l}$ was template DNA. PCR products were run on a 3130xl Genetic

164 Analyzer with GeneScan 500 LIZ (Life Technologies) as internal size standard and analyzed

165 with GeNEMAPPER ${ }^{\circledR}$ Software version 4.0 (Applied Biosystems). Locus Macu40 could not be

166 scored consistently (excessive stutter bands) and was omitted from all further analysis. The

167 overall proportion of alleles that could not be amplified was $4.6 \%$ (see table S1). 
170 The eight microsatellite loci analysed were tested for linkage disequilibrium (genotypic

171 disequilibrium) between all pairs of loci in each sample and for deviations from Hardy-Weinberg

172 proportions using exact tests in FSTAT version 2.9.3.2 (Goudet, 1995) based on 480 and 1260

173 permutations, respectively. The software package MiCRO-CHECKER version 2.2.3 (Van

174 Oosterhout et al., 2004) using 1,000 iterations and a Bonferroni corrected 95\% confidence

175 interval, was employed to test for possible null-alleles.

Population structure, genetic differentiation and kinship

178 We studied the genetic clustering of individual genotypes using the Bayesian algorithm

179 implemented in Structure version 2.3.4 (Falush, Stephens \& Pritchard, 2003, 2007; Hubisz et

180 al., 2009; Pritchard, Stephens \& Donnelly, 2000). The most likely number of genetically distinct

181 clusters $(K)$ was estimated for each $K$ in the range 2 to 12 , allowing for sub-structuring of

182 samples. A burn-in length of 50,000 MCMCs was used to secure approximate statistical

183 stationarity, followed by a simulation run of 500,000 MCMCs using an admixture model with

184 correlated allele frequencies as recommended by Pritchard, Stephens \& Donnelly (2000). No

185 location prior was used, and LnP(D) values were averaged over 20 iterations. The most likely

186 value of $\mathrm{K}$ (number of clusters) was estimated using the $\Delta K$ method of Evanno, Regnaut \&

187 Goudet (2005). To check whether the assumptions inherent in STRUCTURE were biasing our

188 genetic clustering, we also used the Bayesian genetic clustering programs BAPS version 5.2

189 (Corander et al., 2008) and InStRUCT version 1.0 (Gao, Williamson \& Bustamante, 2007), which

190 gave essentially identical results (see Additional Analysis S1, Figures S1, S2). 
191 For more detailed population differentiation, samples were explored individually as well as in

192 four different partitions: (a) pre-defined populations (PoP: Răscruci dry, Răscruci wet and

193 Şardu) which also relates to host plant use (Răscruci wet and Şardu: G. pneumonanthe. Răscruci

194 dry: G. cruciata), (b) host ant use (ANT: Myrmica scabrinodis, My. sabuleti, My. schencki and

195 My. vandeli), (c) host ant nests (NEST: specific nest ID within PoP), and (d) year of sampling

196 (YEAR: 2007 and 2009), the latter to test for potential temporal differences.

197 We studied the overall population differentiation between pre-defined populations (POP)

198 calculating Weir and Cockerham's (1984) estimate of $\mathrm{F}_{\mathrm{ST}}(\theta)$ using FSTAT version 2.9.3.2 based

199 on 1,000 permutations. As the magnitude of the value of $\theta$ is related to the allelic diversity at the

200 marker loci applied, we further calculated the standardized $G^{\prime \prime}$ ST (Meirman \& Hedrick, 2011),

201 and the estimator $D_{\mathrm{EST}}$ (Jost, 2008) as alternative quantifications of genetic differentiation,

202 making comparisons with studies based on other marker loci possible (Meirman \& Hedrick,

203 2011). $G_{\text {ST }}^{\prime \prime}$ and Jost's $D_{\mathrm{EST}}$ for pairs of PoP samples were calculated using GENODIVE version

2042.0 b27 (Meirmans \& Van Tienderen, 2004). Hierarchical AMOVA (Analysis of Molecular

205 Variance: Excoffier, Smouse \& Quattro, 1992) was calculated for PoP, ANT, NEST, and

206 separately for POP and YEAR using the R-package HiERFSTAT (Goudet, 2005) with 9,999

207 permutations to estimate the variance components and their statistical significance. Individual-

208 based Principal Coordinate Analysis (PCOA) with standardized covariances was employed to

209 obtain a multivariate ordination of individual samples based on pairwise genetic distances, as

210 implemented in the software GENAlEx version 6.502 (Peakall \& Smouse, 2012). The PCoA

211 were explored for NEST within ANT within POP across YEAR using nested MANOVA based on

212 the sum of the variances of the different coordinates, as implemented in JMP 12.02 (SAS

213 Institute). 
214 To examine whether the low dispersal ability of Maculinea alcon females could lead to high 215 relatedness between samples of individuals collected in the same nest, pairwise measures of 216 kinship (Loiselle et al., 1995) and relatedness (Queller \& Goodnight 1989) between samples 217 were estimated using GENODIVE and GENALEX respectively. Both of these values estimate the 218 probability that samples share alleles by descent, based on the distribution of alleles in the whole 219 set of samples, with possible values ranging from -1 to +1 . Negative values show that the two 220 individuals compared are less similar in the alleles they share than two randomly picked 221 individuals. Values of kinship and relatedness were then compared between the different 222 partitions of the data using stratified Mantel tests as implemented in GENODIVE. To further test

223 the hypothesis that individuals found in the same nest were likely to derive from eggs laid by the 224 same female, the program Colony (v 2.0.6.1; Jones and Wang 2010) was used to give a 225 maximum likelihood estimate of the probability that any two sampled individuals were likely to 226 be either full or half siblings. Since males of $M$. alcon are much more mobile than females, who 227 tend to oviposit in a limited area (Körösi et al., 2008; D R Nash, unpublished data), this was 228 based on a mating system assuming female polygyny and male monogyny, with other parameters 229 kept at their default values. 


\section{Results}

233 Host ant specificity

234 A total of 135 Myrmica ant nests were found within $2 \mathrm{~m}$ of host gentian plants on the two sites, 235 and 90 Maculinea larvae, pupae and exuviae were found in 26 infested nests (Table 2) including 23687 nests and 56 Maculinea already published in Tartally et al. (2008). Altogether four Myrmica

237 species were found. Only My. scabrinodis was present at all sites, and was the most abundant ant 238 species (59\% of all ant colonies found). This species was used as a host on all three sites. Only a 239 single $M$. alcon $X$ was found in a nest of $M y$. scabrinodis at Răscruci dry despite the dominance 240 of this ant there and its frequent usage by $M$. alcon $H$ on Răscruci wet (Fisher's exact test, $P=$ 241 0.032). The much greater exploitation rates of My. sabuleti and My. schencki led to significant 242 overall host ant specificity at Răscruci dry (Table 2).

244 Genetic diversity and inbreeding

245 Measures of genetic diversity and $F$-statistics generated by FSTAT for each locus are listed in 246 Table S2 in the supporting information. Analysis with MiCRO-CHECKER revealed that Macu29

247 had a highly significant $(P<0.001)$ excess of homozygotes and cases of non-amplification 248 consistent with the presence of a relatively high proportion $(>20 \%)$ of null-alleles, and was 249 therefore excluded from further analysis. All other loci showed no significant deviations from 250 Hardy-Weinberg proportions. Tests for linkage disequilibrium revealed only a few sporadic 251 significant results showing no overall pattern (Table S3), so all loci were retained in further 252 analysis, which was thus based on 7 polymorphic loci. All three of the pre-defined populations 
253 showed no evidence of inbreeding (Table 3), and in fact showed negative values for the

254 inbreeding coefficient $F_{\text {IS }}$ (meaning an excess of heterozygotes), although not significantly so 255 (Table 3).

STRUCTURE analysis revealed rather invariable log-likelihood values for partitioning of the data into genetic clusters, but the highest change in log-probability value was for $\mathrm{K}=2$, with lower maxima at $\mathrm{K}=4$ and $\mathrm{K}=10$ (Figure 1 ). There was a clear overall distinction between samples

261 from Răscruci wet in one genetic group and Răscruci dry and Şardu in another group. Levels of 262 admixture between genetic clusters were generally low, but four individuals from Răscruci wet 263 (from two different My. scabrinodis nests) showed high affinity to the Răscruci dry-Şardu group, 264 irrespective of the value of $K$. One individual found in a My. sabuleti nest at Răscruci dry 265 (sample code: DA14) appeared genetically more similar to those from Răscruci wet. For values 266 of $\mathrm{K}$ higher than 2 there was no additional partitioning between the pre-defined populations, but 267 some substructure in Răscruci wet became apparent for $\mathrm{K}=3$, with two partitions that were 268 relatively dissimilar, while for $\mathrm{K} \geq 4$ no additional grouping of individuals was apparent (Figure $2691)$.

272 We found significant overall genetic differentiation between pre-defined populations $(\theta=0.090$, $273 D_{\mathrm{EST}}=0.215 ;$ Table S2). Pairwise genetic differentiation measures $\theta, G^{\prime \prime}{ }_{\mathrm{ST}}$ and $D_{\mathrm{EST}}$ were 
274 significant for all population comparisons after Bonferroni adjustment $(P<0.003$; Table 3$)$. There

275 was no evidence of inbreeding, either overall $\left(F_{\text {IS }}=-0.074\right.$, Table S2), or within pre-defined

276 populations (Table 3 ).

277 Hierarchical AMOVA (Table 4) revealed that most genetic variance (93.4\%) was within

278 individuals, but that significant variation was also explained by POP and NEST. The proportion

279 of variation and inbreeding coefficients for individuals within NEST and ANT were both

280 negative, indicating that there was greater heterozygosity between individuals in the same nest

281 and between samples across different Myrmica species than between randomly chosen samples

282 from the data set. Samples from different years explained only $0.12 \%$ of the genetic variance in a

283 separate AMOVA $(P=0.354)$. The Principal Coordinate Analysis retained a total of six principal

284 coordinates with eigenvalues greater than 1 , which together explained $52 \%$ of the variance in 285 genetic distance $(13.5 \%, 10.3 \%, 8.4 \%, 8.0 \%, 7.2 \%$ and $4.5 \%$ for coordinates $1-6$ respectively;

286 see figure S3 for more details). These showed a similar result to the AMOVA where YEAR 287 samples (2007 and 2009) overlapped completely in genetic ordination space $\left(\mathrm{F}_{1,36}=8.91 \times 10^{-16}\right.$, $288 P=0.999)$, while samples from Răscruci wet were separated from those from Răscruci dry and 289 Şardu (Figure 2; $\mathrm{F}_{2,36}=6.08, \mathrm{P}=0.005$ ). We found a pronounced structuring of samples when 290 examining nests within pre-defined populations $\left(\mathrm{F}_{18,36}=3.59, P<0.001\right)$, with samples from the

291 same nest clustering together, but there was no consistent clustering of samples from the nests of 292 the same host ant species $\left(\mathrm{F}_{3,36}=0.887, P=0.457\right)$. The single sample from Răscruci dry that 293 was collected from a My. scabrinodis nest (sample code DB15) had a first principal component 294 that was more characteristic of samples from Răscruci wet (which all used this host ant species; 295 figure 2), but was not assigned to this population in the Bayesian analysis (figure 1). 
298 Overall pairwise relatedness of individuals (Figure 3) sampled from the same nest (0.311) was

299 significantly higher than that of those sampled from different nests within the same site $(-0.032$;

300 Stratified Mantel test: $\left.r^{2}=0.069, P=<0.0001\right)$. Looking at individual sites, the same pattern was

301 found at both $M$. alcon $H$ sites (Răscruci wet: within-nest relatedness $=0.32$, between nests =

$3020.10, r^{2}=0.130, P=0.0002$; Şardu: within-nest $=0.249$, between nests $=0.065, r^{2}=0.126, P=$

303 0.002), but relatedness was not significantly different within and between nests at Răscruci dry

304 (within-nest $=0.003$, between nests $=0.081, r^{2}=0.001, P=0.448$ ). Similar results were found

305 when analysing pairwise kinship (see figure S4 and Additional Analysis S2). Maximum-

306 likelihood analysis using COLONY identified 38 pairs of individuals as potential full siblings

307 (with probabilities ranging from 0.002 to 0.935 ; Figure 3), and 161 as potential half siblings

308 (with probabilities ranging from 0.002 to 0.742 ; Figure S4). For the 21 pairs with high $(>0.5)$

309 probability of being full siblings, $13(62 \%)$ were from the same nest, six were from nests of the

310 same ant species at the same site, and only two were from different sites, both including

311 individual SCA86-2 from Răscruci wet, which appears closely related to two individuals (DA14

312 and SAB67-1) from different Myrmica nests from Răscruci dry (Figure 3). This last result

313 probably reflects the non-amplification of characteristic loci for these individuals (see table S1),

314 so that they share common alleles without being related. Within sites, a high proportion of

315 individuals from both Răscruci wet (60.4\%) and Şardu (37.5\%) from multiply-infested nest had

316 individuals estimated to be full siblings in the same nest (overall $52.9 \%$, Generalized linear

317 model with binomial errors and Firth corrected maximum likelihood, comparing sites:

318 Likelihood-ratio $\chi^{2}=0.73$ d.f. $\left.=1, P=0.391\right)$. However, none of the $M$. alcon $X$ individuals 
319 sharing nests at Răscruci dry were estimated to be full siblings (M. alcon $X$ vs. M. alcon H:

320 Likelihood-ratio $\chi^{2}=9.72$, d.f. $=1, P=0.002$ ).

321 Although there was evidence for strong within-nest relatedness of individuals, the patterns of

322 genetic diversity and differentiation were not strongly affected by this, and were unaffected when 323 analyses were repeated with only a single individual from each nest (see table S4). 


\section{Discussion}

327 This study gives the first comparison of the host ant specificity and genetic composition of $M$. 328 alcon $H$ and $M$. alcon $X$ within the same site.

329 The host ant specificity found in this study confirm the earlier results of Tartally et al. (2008) that

330 these populations use the typical host ants found in other Central European studies (Höttinger,

331 Schlick-Steiner \& Steiner, 2003; Sielezniew \& Stankiewicz, 2004; Steiner et al., 2003; Tartally

332 et al., 2008; Witek et al., 2008). M. alcon $H$ was found exclusively with My. scabrinodis at

333 Răscruci wet and also with $M y$. vandeli at Şardu, but M. alcon $X$ was found mainly with $M y$.

334 sabuleti and My. schencki at Răscruci dry. Interestingly only one M. alcon X was found with $M y$.

335 scabrinodis, despite this Myrmica species being the most numerous at Răscruci dry (Table 2) and

336 being the main host of $M$. alcon $X$ in two other sites in the Carpathian-Basin (Tartally et al.,

337 2008). My. scabrinodis usage could therefore be a potential link between the $M$. alcon $H$ and $M$.

338 alcon $X$ populations at Răscruci (and probably in some other regions), but $M$. alcon $X$ shows a

339 clear separation from the $M$. alcon $H$ in the proportional usage of this host ant. The background

340 of this separation in the host ant specificity of $M$. alcon $H$ and $M$. alcon $X$ at Răscruci is not

341 clear, but could reflect the dynamic arms race between the different genetic lineages of $M$. alcon

342 and local host ants (Nash et al., 2008).

343 Our genetic results (Figures 1, 2) show strong genetic differentiation between $M$. alcon $H$ and $M$.

344 alcon $X$ at Răscruci, indicating limited gene flow between these two groups, although it is

345 interesting to note that a few individuals had genotypes more characteristic of the other

346 population. This differentiation is likely due to separation in time rather than space because of

347 the different phenology of the host plants, which results in largely non-overlapping flying 
348 seasons of $M$. alcon $H$ and $M$. alcon $X$ (Timuş et al., 2013). This may be reinforced by lowered

349 fitness of any hybrid individuals that would emerge during the approximately 2 -week gap when

350 neither host plant is suitable for oviposition.

351 The lowest level of between-population differentiation, on the other hand, was between M. alcon

$352 X$ from Răscruci and M. alcon $H$ from Şardu, and Bayesian population assignment suggests that

353 these are so similar that they have almost certainly been part of a single population. This

354 supports previous findings of no overall phylogenetic differentiation between the two forms of

355 M. alcon (Als et al., 2004; Fric et al., 2007; Ugelvig et al., 2011b), and that the two forms tend to

356 be more genetically similar regionally than either is to more distant populations that use the same

357 host plant (Bereczki et al., 2005; Bereczki, Pecsenye \& Varga, 2006; Pecsenye et al., 2007).

358 Hence the two forms cannot be regarded as host races (Drès \& Mallet, 2002), since they do not

359 fulfil the criterion of spatial and temporal replicability. Genetic analysis of several Polish and

360 Lithuanian M. alcon populations using microsatellite markers (Sielezniew et al., 2012) gave

361 similar results to ours (Figures 1,2) in that there was no clear pattern reflecting genetic division

362 into two ecotypes. Sielezniew et al. also found that the M. alcon $X$ ecotype was less polymorphic,

363 and its populations more differentiated than those of the $M$. alcon $H$ ecotype. Their data also

364 suggest that $M$. alcon $H$ populations form a single clade but $M$. alcon $X$ can be split into more

365 clades, suggesting that $M$. alcon $H$ is an ancestral form and that $M$. alcon $X$ represents a group of

366 independently evolved $M$. alcon $H$ populations that have switched to use dryer habitats with the

367 locally available Gentiana and Myrmica species. They propose that the background of this

368 pattern may be independent specialisations on different host ant species, since in their study

369 clades of $M$. alcon $X$ largely reflected host ant use. However, we find no evidence of genetic

370 differentiation associated with host-ant usage at Răscruci or Şardu (Figures 1, 2, 3), and no 
371 difference in genetic diversity in populations of the two ecotypes (table 3). Due to the relatively

372 large distances and potential barriers between Răscruci and Şardu it is unlikely that there has

373 been recent gene-flow between the two sites, which suggests that Răscruci was likely colonized

374 at least twice from two different gene pools, and that the ancestors of the Răscruci wet

375 population are no longer locally extant (or have evaded detection).

376 The higher within-nest than between-nest relatedness between individuals of M. alcon $H$ is

377 consistent with observations of limited dispersal of ovipositing females (Körösi et al., 2008)

378 which is likely to lead to substantial within-population substructure between nests, as found here.

379 The additional grouping of individuals from $\mathrm{K}=2$ to $\mathrm{K}=4$ in our population assignment analysis

380 groups families of relatives within populations. Our parentage analysis confirms the relatively

381 high probability that M. alcon $H$ caterpillars infesting the same Myrmica nest are relatives, and in

382 around $50 \%$ of cases may be full siblings. The lack of any association between relatedness and

383 infestation of nests for $M$. alcon $X$ from the Răscruci dry site is consistent with the difference in

384 oviposition strategy and mobility of butterflies from this population compared with those from

385 the Răscruci wet site (Czekes et al., 2014; Timuş et al., 2013).

386 Given the small size of these M. alcon populations (Timuş et al., 2013) and their low dispersal

387 (Körösi et al. 2008), it is interesting to note that there is no evidence of inbreeding among the

388 individuals that we examined, and that estimated inbreeding coefficients ( $F_{\mathrm{IS}}$ and $\left.G_{\mathrm{IS}}\right)$ were

389 negative. This means that individuals were more heterozygous than expected if mating were

390 random (albeit not significantly so), which is probably a result of difference in mating strategy of

391 males and females. Males are highly mobile, and tend to patrol a large area while seeking

392 females, whereas females are rather sedentary, and are often mated immediately after emerging

393 from the Myrmica nest in which they developed, and then go on to lay eggs on host plants 
394 relatively close by (Körösi et al., 2008). This means that females are unlikely to be related to

395 their mates, and may in fact be less related to them than to a randomly chosen male, because

396 males pupate and emerge several days before females (Meyer-Hozak, 2000). This, together with

397 the observation that caterpillars that develop in the same Myrmica nest may be offspring of the

398 same female, can easily lead to the negative inbreeding indices observed both overall, and for

399 individuals within Myrmica nests and host ant species within pre-defined populations within our 400 hierarchical AMOVA.

401 Regardless of its origin, it is clear that the M. alcon $X$ population at Răscruci is ecologically

402 highly differentiated from the local $M$. alcon $H$ populations in terms of its host plant and host ant 403 use, as well as in its behaviour (Czekes et al., 2014; Timuş et al., 2013). The pattern of 404 differentiation we see is not that typically associated with speciation via host race formation 405 (Drès \& Mallet, 2002), since the two forms do not fulfil the criterion of spatial and temporal 406 replicability (i.e. "are more genetically differentiated from populations on another host in 407 sympatry (and at the same time) than at least some geographically distant populations on the 408 same host"; Drès \& Mallet, 2002, p. 473-4). M. alcon X cannot, therefore, represent an 409 evolutionarily significant unit in conservation terms as usually defined, but we would argue that 410 it should still be regarded as a functional conservation unit (Casacci, Barbero \& Balletto, 2013).

411 The site at Răscruci represents the only known area where both forms of $M$. alcon occur 412 syntopically, and so is of particular value to research on speciation, and has great potential for 413 examining adaptation at non-neutral genetic markers. This is enhanced by the occurrence of two 414 other Maculinea species on the same site; M. teleius Bergsträsser (Tartally \& Varga, 2008) and 415 M. nausithous kijevensis Sheljuzhko (Rákosy et al., 2010; Tartally \& Varga, 2008), as well as the 416 Myrmica parasites Microdon myrmicae Schönrogge et al. (Diptera: Syrphidae; Bonelli et al., 
417 2011) and Rickia wasmannii Cavara (Ascomycota: Laboulbeniales; Tartally, Szücs \& Ebsen, 418 2007). The Maculinea spp. parasitoid Ichneumon eumerus Wesmael (Hymenoptera: 419 Ichneumonidae) is also present (Tartally, 2008). Most of these species are also found at Şardu 420 (except $M$. alcon $X$ and $M$. nausithous: Tartally, 2008). It should be emphasized that all of these 421 species can be found in the nests of, and ultimately depend on, My. scabrinodis (as well as other 422 Myrmica species: see Witek, Barbero \& Markó (2014) for a review), providing a unique 423 opportunity to examine a complex set of parasitic interactions revolving around a single keystone 424 ant species.

425

426 


\section{Conclusion}

428 Our analysis of Maculinea alcon from a unique site where both the xerophilous and hygrophilous

429 forms of this butterfly are found within tens of meters of each other has demonstrated strong 430 genetic differentiation between the two forms. However, the xerophilous form was not 431 significantly differentiated from the next closest known population of the hygrophilous form. 432 This supports other recent work suggesting that the hygrophilous and xerophilous forms are not 433 separate species or even subspecies, and that the name $M$. rebeli has frequently been applied to 434 the xerophilous form incorrectly. There is some overlap in host ant species use between the two 435 forms, so the most likely proximate reason for the local genetic differentiation found is 436 differences in host plant phenology. We suggest that since the two different forms of M. alcon do 437 not have a separate evolutionary history, they cannot be regarded as "evolutionarily significant 438 units" for conservation as the term was originally used (Bowen \& Roman, 2005; Casacci, 439 Barbero \& Balletto, 2013). However, since they represent current ecological diversification of 440 the group, and may have different evolutionary potentials (e.g. through selection on different 441 enzyme systems; Bereczki et al., 2015), they should continue to be treated as separate 442 management units for long-term conservation (Bowen \& Roman, 2005; Casacci, Barbero \& 443 Balletto, 2013). Hence we support the continued separation of the two forms in future studies to 444 further explore their evolutionary trajectories and conservation potential. 


\section{Acknowledgements}

448 We thank Tibor-Csaba Vizauer, László Rákosy and Zoltán Varga for assistance in the field and

449 Shukriya Barzinci, Maria Mikkelsen and Sylvia Mathiasen for assistance in the laboratory.

450 Zoltán Varga, Enikő Tóth, Simona Bonelli and Robert Toonen provided valuable comments on 451 earlier versions of the manuscript. 


\section{References}

453 Akino T, Knapp JJ, Thomas JA, Elmes GW. 1999. Chemical mimicry and host specificity in the 454 butterfly Maculinea rebeli, a social parasite of Myrmica ant colonies. Proceedings of the 455 Royal Society of London, Series B: Biological Sciences 266: 1419-1426. DOI: 10.1098/rspb.1999.0796.

Als TD, Vila R, Kandul NP, Nash DR, Yen SH., Hsu YF, Mignault AA, Boomsma JJ, Pierce NE. 2004. The evolution of alternative parasitic life histories in large blue butterflies. Nature 432: 386-390. DOI: 10.1038/nature03020.

Barbero F, Thomas JA, Bonelli S, Balletto E, Schönrogge K. 2009. Queen ants make distinctive sounds that are mimicked by a butterfly social parasite. Science 323: 782-785. DOI:

462 10.1126/science. 1163583.

Bereczki J, Pecsenye K, Peregovits L, Varga Z. 2005. Pattern of genetic differentiation in the Maculinea alcon species group (Lepidoptera, Lycaenidae) in Central Europe. Journal of Zoological Systematics and Evolutionary Research 43: 157-165. DOI: 10.1111/j.14390469.2005.00305.x.

Bereczki J, Pecsenye K, Varga Z. 2006. Geographical versus food plant differentiation in populations of Maculinea alcon (Lepidoptera: Lycaenidae) in Northern Hungary. European Journal of Entomology 103: 725-732. DOI: 10.14411/eje.2006.096. the social parasitic Maculinea butterflies (Lepidoptera: Lycaenidae). Organisms Diversity and Evolution 15: 591-607. DOI:10.1007/s13127-015-0217-7 
473 Bonelli S, Witek M, Canterino S, Sielezniew M, Stankiewicz-Fiedurek A, Tartally A, Balletto E, 474 Schönrogge K. 2011. Distribution, host specificity, and the potential for cryptic speciation 475 in the hoverfly Microdon myrmicae (Diptera: Syrphidae), a social parasite of Myrmica 476 ants. Ecological Entomology 36: 135-143. DOI: 10.1111/j.1365-2311.2010.01253.x.

Bowen, BW, Roman JOE. 2005. Gaia's Handmaidens: The Orlog Model for Conservation Biology. Conservation Biology 19: 1037-1043. DOI: 10.1111/j.1523-1739.2005.00100.x

Casacci LP, Barbero F, Balletto E. 2013. The "evolutionarily significant unit” concept and its applicability in biological conservation. Italian Journal of Zoology 81: 182-193. doi:10.1080/11250003.2013.870240

482 483 484 485 486

Corander J, Marttinen P, Sirén J, Tang J. 2008. Enhanced Bayesian modelling in BAPS software for learning genetic structures of populations. BMC Bioinformatics 9: 539. DOI: $10.1186 / 1471-2105-9-539$.

Czekes Z, Markó B, Nash DR, Ferencz M, Lázár B, Rákosy L. 2014. Differences in oviposition strategies between two ecotypes of the endangered myrmecophilous butterfly Maculinea alcon (Lepidoptera: Lycaenidae) under unique syntopic conditions. Insect Conservation and Diversity 7: 122-131. DOI: 10.1111/icad.12041.

Drès, M, Mallet J. 2002. Host races in plant-feeding insects and their importance in sympatric speciation. Philosophical Transactions of the Royal Society of London, Series B: Biological Sciences 357: 471-492. DOI: 10.1098/rstb.2002.1059

Elmes GW, Thomas JA, Wardlaw JC, Hochberg ME, Clarke RT, Simcox DJ. 1998. The ecology of Myrmica ants in relation to the conservation of Maculinea butterflies. Journal of Insect Conservation 2: 67-78. DOI: 10.1023/A:1009696823965. 
495 Evanno G, Regnaut S, Goudet J. 2005. Detecting the number of clusters of individuals using the 496 software STRUCTURE: a simulation study. Molecular Ecology 14: 2611-2620. DOI:

497

498

499

500

501

502

503

504

505

506

507

508

509

510

511

512

513

514 Goudet, J. 2005. HIERFSTAT, a package for R to compute and test hierarchical F-statistics.

515

516

517 10.1111/j.1365-294X.2005.02553.x.

Excoffier L, Smouse PE, Quattro JM. 1992. Analysis of molecular variance inferred from metric distances among DNA haplotypes - application to human mitochondrial-DNA restriction data. Genetics 131: 479-491.

Falush D, Stephens M, Pritchard JK. 2003. Inference of population structure using multilocus genotype data: linked loci and correlated allele frequencies. Genetics 164: 1567-1587.

Falush D, Stephens M, Pritchard JK. 2007. Inference of population structure using multilocus genotype data: dominant markers and null alleles. Molecular Ecology Notes 7: 574-578. DOI: $10.1111 /$ j.1471-8286.2007.01758.x.

Fric Z, Wahlberg N, Pech P, Zrzavy J. 2007. Phylogeny and classification of the PhengarisMaculinea clade (Lepidoptera: Lycaenidae): total evidence and phylogenetic species concepts. Systematic Entomology 32: 558-567. DOI: 10.1111/j.1365-3113.2007.00387.x.

Gao H, Williamson S, Bustamante CD. 2007. A Markov chain Monte Carlo approach for joint inference of population structure and inbreeding rates from multilocus genotype data. Genetics 176: 1635-1651. DOI: 10.1534/genetics.107.072371.

Goudet J. 1995. FSTAT (version 1.2): a computer program to calculate F-statistics. Journal of Heredity 86: 485-486. Molecular Ecology Notes 5: 184-186. DOI: 10.1111/j.1471-8278 .2004.00828.x

Habeler H. 2008. Die subalpin-alpinen Lebensräume des Bläulings Maculinea rebeli (Hirscke, 1904) in den Ostalpen (Lepidoptera, Lycaenidae). Joannea - Zoologie 10: 143-164. 
518 Höttinger H, Schlick-Steiner BC, Steiner FM. 2003. The Alcon blue Maculinea alcon

519 (Lepidoptera: Lycaenidae) in eastern Austria: status and conservation measures. Ekologia $520 \quad$ (Bratislava) 22: 107-118.

521 Hubisz MJ, Falush D, Stephens M, Pritchard JK. 2009. Inferring weak population structure with 522 the assistance of sample group information. Molecular Ecology Resources 9: 1322-1332. DOI: 10.1111/j.1755-0998.2009.02591.x.

524 Jones OR, Wang J. 2010. COLONY: a program for parentage and sibship inference from multilocus genotype data. Molecular Ecology Resources 10: 551-555.

526 Jost L. 2008. $G_{\mathrm{ST}}$ and its relatives do not measure differentiation. Molecular Ecology 17: 40154026. DOI: 10.1111/j.1365-294X.2008.03887.x.

528 Körösi Á, Örvössy N, Batáry P, Kövér S, Peregovits L. 2008. Restricted within-habitat 529 movement and time-constrained egg laying of female Maculinea rebeli butterflies. Oecologia 156: 455-464. DOI: 10.1007/s00442-008-0986-1.

531 Kudrna O, Belicek J. 2005. On the "Wiener Verzeichnis", its authorship and the butterflies named therein. Oedippus 23: 1-32.

533 Kudrna O, Fric ZF. 2013. On the identity and taxonomic status of Lycaena alcon rebeli 534 HIRSCHKE, 1905 - a long story of confusion and ignorance resulting in the fabrication of a "ghost species" (Lepidoptera: Lycaenidae). Nachrichten des Entomologischen Vereins Apollo 34: 117-124.

537 Loiselle BA, Sork VL, Nason J, Graham C. 1995. Spatial genetic structure of a tropical 538 understory shrub, Psychotria officinalis (Rubiaceae). American Journal of Botany 82: $1420-1425$. 
540 Maes D, Vanreusel W, Talloen W, Van Dyck H. 2004. Functional conservation units for the

541 endangered Alcon Blue butterfly Maculinea alcon in Belgium (Lepidoptera: Lycaenidae).

542 Biological Conservation 120: 229-241. DOI: 10.1016/j.biocon.2004.02.018.

543 Meirmans PG, Van Tienderen PH. 2004. GENOTYPE and GENODIVE: two programs for the 544 analysis of genetic diversity of asexual organisms. Molecular Ecology Notes 4: 792-794

545 Meirmans PG, Hedrick PW. 2011. Assessing population structure: $\mathrm{F}_{\mathrm{ST}}$ and related measures.

546 Molecular Ecology Resources 11: 5-18. doi: 10.1111/j.1755-0998.2010.02927.x

547 Meyer-Hozak C. 2000. Population biology of Maculinea rebeli (Lepidoptera: Lycaenidae) on the

$548 \quad$ chalk grassland of Eastern Westphalia (Germany) and implications for conservation.

549 Journal of Insect Conservation 4: 63-72. DOI: 10.1023/A:1009695031802.

550 Munguira ML, Martín J, eds. 1999. Action Plan for the Maculinea butterflies in Europe. Nature and Environment 97. Strasbourg: Council of Europe Publishing.

552 Nash DR, Als TD, Maile R, Jones GR, Boomsma JJ. 2008. A mosaic of chemical coevolution in 553 a large blue butterfly. Science 319: 88-90. DOI: 10.1126/science.1149180.

554 Oostermeijer JGB, Vantveer R, Dennijs JCM. 1994. Population structure of the rare, long lived

555

556

557

558

559

560

561

562 perennial Gentiana pneumonanthe in relation to vegetation and management in the Netherlands. Journal of Applied Ecology 31: 428-438.

Peakall R, Smouse PE. 2012. GenAlEx 6.5: Genetic analysis in Excel. Population genetic software for teaching and research - an update. Bioinformatics 28: 2537-2539. DOI: 10.1093/bioinformatics/bts460

Pech P, Fric Z, Konvicka M, Zrzavy J. 2004. Phylogeny of Maculinea blues (Lepidoptera : Lycaenidae) based on morphological and ecological characters: evolution of parasitic myrmecophily. Cladistics 20: 362-375. DOI: 10.1111/j.1096-0031.2004.00031.x. 
563 Pecsenye K, Bereczki J, Tihanyi B, Toth A, Peregovits L, Varga Z. 2007. Genetic differentiation

564 among the Maculinea species (Lepidoptera: Lycaenidae) in eastern Central Europe.

565 Biological Journal of the Linnean Society 91: 11-21. DOI: 10.1111/j.1095-

$566 \quad$ 8312.2007.00781.x.

567 Pritchard JK, Stephens M, Donnelly P. 2000. Inference of population structure using multilocus $568 \quad$ genotype data. Genetics 155: 945-959.

569 Queller DC, Goodnight KF. 1989. Estimating relatedness using genetic markers. Evolution 43: $570 \quad 258-275$.

571 Radchenko AG, Elmes GW. 2010. Myrmica ants (Hymenoptera: Formicidae) of the Old World. 572 Warsaw: Natura Optima Dux Foundation.

573 Rákosy L, Tartally A, Goia M, Mihali C, Varga Z. 2010. The Dusky Large Blue - Maculinea 574 nausithous kijevensis (Sheljuzhko, 1928) in the Transylvanian basin: new data on 575 taxonomy and ecology. Nota Lepidopterologica 33: 31-37.

576 Seifert B. 1988. A taxonomic revision of the Myrmica species of Europe, Asia Minor, and

577 Caucasus (Hymenoptera, Formicidae). Abhandlungen und Berichte des

$578 \quad$ Naturkundemuseums Görlitz 62: 1-75.

579 Settele J, Kühn E, Thomas JA, eds. 2005. Studies on the ecology and conservation of butterflies $580 \quad$ in Europe - Vol. 2: species ecology along a European gradient: Maculinea butterflies as a $581 \quad$ model. Sofia: Pensoft. 
582 Sielezniew M, Rutkowski R, Ponikwicka-Tyszko D, Ratkiewicz M, Dziekanska I, Svitra G.

583 2012. Differences in genetic variability between two ecotypes of the endangered

584 myrmecophilous butterfly Phengaris ( = Maculinea) alcon - the setting of conservation

585 priorities. Insect Conservation and Diversity 5: 223-236. DOI: 10.1111/j.1752-

$586 \quad$ 4598.2011.00163.x.

587 Sielezniew M, Stankiewicz AM. 2004. Simultaneous exploitation of Myrmica vandeli and $M$.

588 scabrinodis. European Journal of Entomology 101: 693-696. DOI: 10.14411/eje.2004.091.

589 Steiner FM, Sielezniew M, Schlick-Steiner BC, Höttinger H, Stankiewicz A, Górnicki A. 2003.

$590 \quad$ Host specificity revisited: New data on Myrmica host ants of the lycaenid butterfly

591 Maculinea rebeli. Journal of Insect Conservation 7: 1-6. DOI: 10.1023/A:1024763305517.

592 Tartally A. (2008) Myrmecophily of Maculinea butterflies in the Carpathian Basin (Lepidoptera:

593 Lycaenidae). PhD thesis, University of Debrecen.

594 Tartally A, Koschuh A, Varga Z. 2014. The re-discovered Maculinea rebeli (Hirschke, 1904):

595 Host ant usage, parasitoid and initial food plant around the type locality with taxonomical

596 aspects (Lepidoptera, Lycaenidae). ZooKeys 406: 25-40. DOI: 10.3897/zookeys.406.7124.

597 Tartally A, Nash DR, Lengyel S, Varga Z. 2008. Patterns of host ant use by sympatric

598 populations of Maculinea alcon and M. 'rebeli' in the Carpathian Basin. Insectes Sociaux

599 55: 370-381. DOI: 10.1007/s00040-008-1015-4.

600 Tartally A, Szücs B, Ebsen JR. (2007) The first records of Rickia wasmannii Cavara, 1899, a

601 myrmecophilous fungus, and its Myrmica Latreille, 1804 host ants in Hungary and

602 Romania (Ascomycetes: Laboulbeniales; Hymenoptera: Formicidae). Myrmecological

$603 \quad$ News 10: 123. 
604 Tartally A, Varga Z. 2008. Host ant use of Maculinea teleius in the Carpathian-Basin

605 (Lepidoptera: Lycaenidae). Acta Zoologica Academiae Scientiarum Hungaricae 54: 257-

606268.

607 Thomas JA, Elmes GW. 1998. Higher productivity at the cost of increased host-specificity when

608 Maculinea butterfly larvae exploit ant colonies through trophallaxis rather than by

609 predation. Ecological Entomology 23: 457-464. DOI: 10.1046/j.1365-2311.1998.00153.x.

610 Thomas JA, Elmes GW, Schönrogge K, Simcox DJ, Settele J. 2005. Primary hosts, secondary

611 hosts and 'non-hosts': common confusions in the interpretation of host specificity in

612 Maculinea butterflies and other social parasites of ants. In: Settele J, Kuhn E, Thomas JA,

613 eds. Studies on the ecology and conservation of butterflies in Europe - Vol. 2: species

614 ecology along a European gradient: Maculinea butterflies as a model. Pensoft, Sofia. 99-

$615 \quad 104$

616 Thomas JA, Elmes GW, Wardlaw JC, Woyciechowski M. 1989. Host specificity among

617 Maculinea butterflies in Myrmica ant nests. Oecologia 79: 452-457. DOI:

$618 \quad 10.1007 / \mathrm{BF} 00378660$

619 Thomas JA, Settele J. 2004. Evolutionary biology: butterfly mimics of ants. Nature 432: 283-

620 284. DOI: $10.1038 / 432283 a$.

621 Timuş N, Craioveanu C, Sitaru C, Rus A, Rákosy L. 2013. Differences in adult phenology, 622 demography, mobility and distribution in two syntopic ecotypes of Maculinea alcon 623 (cruciata vs. pneumonanthe) (Lepidoptera: Lycaenidae) from Transilvania (Romania).

624 Entomologica Romanica 18: 21-30. 
625 Ugelvig LV, Andersen A, Boomsma JJ, Nash DR. 2012. Dispersal and gene flow in the rare, 626 parasitic Large Blue butterfly Maculinea arion. Molecular Ecology 21: 3224-3236. DOI: 10.1111/j.1365-294X.2012.05592.x.

628 Ugelvig LV, Nielsen PS, Boomsma JJ, Nash DR. 2011a. Reconstructing eight decades of genetic 629 variation in an isolated Danish population of the large blue butterfly Maculinea arion. BMC Evolutionary Biology 11:201. DOI: 10.1186/1471-2148-11-201.

631 Ugelvig LV, Vila R, Pierce NE, Nash DR. 2011b. A phylogenetic revision of the Glaucopsyche 632 section (Lepidoptera: Lycaenidae), with special focus on the Phengaris-Maculinea clade. Molecular Phylogenetics and Evolution 61: 237-243. DOI: 10.1016/j.ympev.2011.05.016.

Van Oosterhout C, Hutchinson WF, Wills DPM, Shipley P. 2004. MICRO-CHECKER: software for identifying and correcting genotyping errors in microsatellite data. Molecular Ecology Verstrael T, Warren M, Wiemers M, Wynhof I. 2010. European Red List of Butterflies. Brussels: IUCN. DOI:10.2779/83897

Weir BS, Cockerham CC. 1984. Estimating F-statistics for the analysis of population structure. Evolution 38: 1358-1370. DOI: 10.2307/2408641.

642 Witek M, Barbero F, Markó B. 2014. Myrmica ants host highly diverse parasitic communities: 643 from social parasites to microbes. Insectes Sociaux 61: 307-323. DOI: 10.1007/s00040644 014-0362-6. 
645 Witek M, Śliwińska EB, Skórka P, Nowicki P, Wantuch M, Vrabec V, Settele J, Woyciechowski

646 M. 2008. Host ant specificity of large blue butterflies Phengaris (Maculinea) (Lepidoptera:

647 Lycaenidae) inhabiting humid grasslands in East-central Europe. European Journal of

648 Entomology 105: 871-877. DOI: 10.14411/eje.2008.115.

649 Wynhoff I. 1998. The recent distribution of the European Maculinea species. Journal of Insect

650 Conservation 2: 15-27. DOI: 10.1023/A:1009636605309. 


\section{Table $\mathbf{1}$ (on next page)}

Details of microsatellites used in this study

$\mathrm{SR}=$ product size range (base pairs), $\mathrm{T}_{\mathrm{A}}=$ Annealing Temperature $(\stackrel{\circ}{ } \mathrm{C})$, Primer dye and Multiplex group, $\mathrm{N}_{\mathrm{a}}=$ Number of alleles. Ref. = Reference source (U11 = Ugelvig et al. 2011a, U12 = Ugelvig et al. 2012, New = This study). Primer concentration in the PCR mix is given below the table. 


\begin{tabular}{|c|c|c|c|c|c|c|c|c|}
\hline Primer & SSR motif & Primer sequences 5' - 3' & SR & $\mathrm{T}_{\mathrm{A}}$ & $\begin{array}{l}\text { Dye and } \\
\text { Multiplex }\end{array}$ & $\mathrm{N}_{\mathrm{a}}$ & $\begin{array}{l}\text { Genbank } \\
\text { accession }\end{array}$ & Ref. \\
\hline Macu20 & $(\mathrm{CT})_{\mathrm{n}}(\mathrm{AT})_{\mathrm{n}}(\mathrm{CT})_{\mathrm{n}}$ & $\begin{array}{l}\text { F: TGGCCCGATTTCCTCTAAAC } \\
\text { R: TGCGTGTTTATTTTCATTTTAACAG }\end{array}$ & $92-122$ & 57 & Fam 1 & 9 & HM535963 & U12 \\
\hline Macu26 & $(\mathrm{CA})_{\mathrm{n}}$ & $\begin{array}{l}\text { F: CTCCCGGGATAGCATTGAC } \\
\text { R: CATTGTCGCGGTCGTAATTC }\end{array}$ & $92-128$ & 57 & Ned 2 & 7 & HM535964 & U12 \\
\hline Macu28 & $(\mathrm{CA})_{\mathrm{n}}(\mathrm{CGCA})_{\mathrm{n}}(\mathrm{CA})_{\mathrm{n}}$ & $\begin{array}{l}\text { F: TTTTAATCAAAATCGGTTCATCC } \\
\text { R: TCAACCACAAAGCAAGTGAGTC }\end{array}$ & $195-223$ & 57 & Fam2 & 12 & KT851400 & New \\
\hline Macu30 & $(\mathrm{TG})_{\mathrm{n}}$ & $\begin{array}{l}\text { F: GACGCGCTGTTATGTATTGC } \\
\text { R: CGTCTAGCGTGACCGTAACA }\end{array}$ & 93-109 & 57 & Pet 4 & 5 & HM586096 & U11 \\
\hline Macu31 & $(\mathrm{GTA})_{\mathrm{n}}(\mathrm{GTC})_{\mathrm{n}}(\mathrm{GTA})_{\mathrm{n}}$ & $\begin{array}{l}\text { F: GTTCTGTCCCCCGAACTAGG } \\
\text { R: AAACCTGGGATTGGTTAAAAAC }\end{array}$ & $110-173$ & 62 & Ned 5 & 5 & HM586097 & U11 \\
\hline Macu45 & $(\mathrm{AC})_{\mathrm{n}}(\mathrm{GC})_{\mathrm{n}}(\mathrm{AC})_{\mathrm{n}}$ & $\begin{array}{l}\text { F: TGTGTGACTGCGGTTCTTATC } \\
\text { R: TGTAATCGCAGGAGAGATGTG }\end{array}$ & $145-217$ & 57 & Vic 4 & 20 & HM535966 & U12 \\
\hline
\end{tabular}

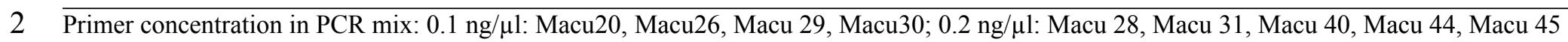




\section{Table 2 (on next page)}

Details of sampled Myrmica nests

The number of nests found within $2 \mathrm{~m}$ of gentians at each site, their infection with $M$. alcon $H$ or $M$. alcon $X$, the number of individual M. alcon used for genetic analysis ("Genetic samples": listed in table S1), and statistical tests of host ant specificity within each site: $P 1=$ probability from Fisher exact test and $P 2=$ probability from a randomization test of ant nests between species. Significant $P$-values $(P<0.05)$ are marked in bold. 


\begin{tabular}{|c|c|c|c|c|c|c|c|c|c|}
\hline Site & Maculinea & Myrmica & $\begin{array}{c}\mathrm{N}^{o .} \\
\text { nests }\end{array}$ & $\begin{array}{l}\mathrm{N}^{o} . \text { with } \\
\text { M.alcon }\end{array}$ & $P 1$ & $\begin{array}{c}\mathrm{N}^{o} \text { of } M . \\
\text { alcon }\end{array}$ & Range & $P 2$ & $\begin{array}{l}\text { Genetic } \\
\text { samples }\end{array}$ \\
\hline \multirow[t]{3}{*}{ Răscruci dry } & alcon $X$ & sabuleti & 10 & 5 & 0.004 & 17 & $1-8$ & 0.002 & 13 \\
\hline & & schencki & 6 & 2 & & 18 & $1-15$ & & 5 \\
\hline & & scabrinodis & 23 & 1 & & 1 & & & 1 \\
\hline Răscruci wet & alcon $H$ & scabrinodis & 31 & 9 & - & 30 & $1-7$ & - & 28 \\
\hline Răscruci both & both & as above & & & 0.078 & & & 0.021 & \\
\hline \multirow[t]{2}{*}{ Şardu } & alcon $H$ & vandeli & 27 & 2 & 0.147 & 9 & $2-7$ & 0.495 & 2 \\
\hline & & scabrinodis & 38 & 7 & & 15 & $1-4$ & & 11 \\
\hline
\end{tabular}

2 


\section{Table 3 (on next page)}

Pairwise differentiation between, and inbreeding and genetic diversity within predefined populations

Values above the diagonal in the matrix (with blue background) are $\theta\left(F_{\mathrm{ST}}\right)$, values along the diagonal (with green background) are $F_{15}$, values below the diagonal (with yellow background) are $G^{\prime \prime}{ }_{\text {ST }} / D_{\mathrm{EST}}$. Values in bold differ significantly from zero $(P<0.001)$. Below the matrix are mean values ( $\pm \mathrm{SE}$ ) of four different measures of within-population genetic diversity. The effective number of alleles per locus $\left(A_{\mathrm{E}}\right)$, the observed heterozygosity $\left(H_{0}\right)$, the expected heterozygosity $\left(H_{\mathrm{E}}\right)$ and the unbiased expected heterozygosity $\left(u H_{\mathrm{E}}\right) . P$-values for comparisons between pre-defined populations based on mixed model comparison across loci are shown on the right. 
1

\begin{tabular}{r|c|c|c|}
\multicolumn{1}{c}{} & \multicolumn{1}{c}{ Răscruci dry } & Răscruci wet & \multicolumn{1}{c}{ Şardu } \\
\cline { 2 - 3 } Răscruci dry & -0.050 & $\mathbf{0 . 0 9 3}$ & $\mathbf{0 . 0 5 9}$ \\
Răscruci wet & $\mathbf{0 . 3 0 2} / \mathbf{0 . 2 5 5}$ & -0.106 & $\mathbf{0 . 1 0 3}$ \\
\cline { 2 - 3 } Şardu & $\mathbf{0 . 2 0 7} / \mathbf{0 . 1 5 1}$ & $\mathbf{0 . 3 3 0} / \mathbf{0 . 2 2 1}$ & -0.052 \\
\cline { 2 - 3 } & &
\end{tabular}

$\begin{array}{ccccc}A_{\mathrm{E}} & 4.000 \pm 0.606 & 3.365 \pm 0.418 & 4.594 \pm 0.909 & 0.131 \\ H_{\mathrm{O}} & 0.707 \pm 0.067 & 0.717 \pm 0.056 & 0.733 \pm 0.090 & 0.944 \\ H_{\mathrm{E}} & 0.707 \pm 0.046 & 0.674 \pm 0.034 & 0.709 \pm 0.063 & 0.781 \\ u H_{\mathrm{E}} & 0.729 \pm 0.048 & 0.687 \pm 0.035 & 0.738 \pm 0.066 & 0.613\end{array}$




\section{Table 4(on next page)}

Hierarchical Analysis of Molecular Variance

Calculated using HierFStat (Goudet, 2005). The F-coefficient gives the estimated inbreeding coefficient (excess of homozygotes) at each hierarchical level. $P$-values are based on 1000 re-samplings of the data. 
1

\begin{tabular}{lccccc}
\hline \multicolumn{1}{c}{ Source } & d.f. & Variance component & \%variance & $F$-coefficient & $P$ \\
\hline Between PoP & 2 & 0.577 & 10.6 & 0.106 & 0.027 \\
ANT within PoP & 3 & -0.257 & -4.7 & -0.053 & 0.956 \\
NEST within ANT & 18 & 0.609 & 11.2 & 0.119 & $<0.001$ \\
Individuals within NEST & 36 & -0.569 & -10.5 & -0.126 & $>0.999$ \\
Within Individuals & 60 & 5.067 & 93.4 & & \\
\hline Total & 119 & 5.427 & & & \\
\hline
\end{tabular}

2

3

4 


\section{Figure legends}

6 Figure 1: Site layout and Bayesian clustering of samples. A) Map showing the relative

7 position of the two sample sites. Shaded areas in the detailed map correspond to $50 \mathrm{~m}$ contour

8 lines. B) Initial food plants of the hygric (G. pneumonanthe) and xeric (G. cruciata) forms of

9 Maculinea alcon. Images modified from WikiMedia commons. C) Posterior probabilities of the

10 number of clusters $(\mathrm{K})$ identified by the Bayesian population assignment program Structure. The

11 solid line shows the mean posterior probability for each value of $\mathrm{K}$, with error bars representing

12 the standard deviation across simulations. The dashed line shows the $\Delta \mathrm{K}$ values of the posterior

13 probabilities from Structure using the method of Evanno, Regnaut \& Goudet (2005) shown

14 relative to the maximum value of $\Delta \mathrm{K}$. Peaks in the value of $\Delta \mathrm{K}$ may represent different levels of

15 population substructure. D) Comparison of genetic clustering of samples into two and four

16 groups using the Bayesian clustering program STRUCTURE without a location prior. Each column

17 represents an individual, and is divided according to its probability of membership of cluster 1

18 (orange), 2 (blue), 3 (black) or 4 (green).

Figure 2: Ordination of samples based on principal coordinate analysis. Each symbol

21 represents an individual, coloured according to its pre-defined population (blue = Răscruci wet,

22 orange $=$ Răscruci dry, purple $=$ Şardu). Coloured lines are convex hulls enclosing all samples

23 from each pre-defined population, while coloured regions are convex hulls enclosing samples

24 collected from the same nest. The single individual (sample DB15) collected from a My.

25 scabrinodis nest at Răscruci dry is shown with a larger symbol. 
26 Figure 3: Relatedness and parentage analysis of samples. The pairwise matrix show the

27 estimated Queller \& Goodnight (1989) relatedness of each pair of individuals (excluding those

28 with negative relatedness) above the diagonal, and the probability that each pair are full siblings

29 based on maximum likelihood estimates from COLONY (Jones \& Wang, 2010) below the diagonal.

30 Comparisons between samples from the same pre-defined population are shaded according to the

31 same colour scheme as Figure 2 (blue = Răscruci wet, orange = Răscruci dry, purple = Şardu).

32 Individuals sharing the same ant nest are outlined with lines in these same colours, and those

33 sharing the same Myrmica species as host are outlines with black lines. The area and shade of each

34 data point is proportional to the relatedness or probability of being full siblings for that pair of

35 individuals. 


\section{Figure 1 (on next page)}

Site layout and Bayesian clustering of samples

A) Map showing the relative position of the two sample sites. Shaded areas in the detailed map correspond to $50 \mathrm{~m}$ contour lines. B) Initial food plants of the hygric (G. pneumonanthe) and xeric (G. cruciata) forms of Maculinea alcon. Images modified from WikiMedia commons. C) Posterior probabilities of the number of clusters $(K)$ identified by the Bayesian population assignment program Structure. The solid line shows the mean posterior probability for each value of $K$, with error bars representing the standard deviation across simulations. The dashed line shows the $\Delta K$ values of the posterior probabilities from Structure using the method of Evanno, Regnaut \& Goudet (2005) shown relative to the maximum value of $\Delta K$. Peaks in the value of $\Delta K$ may represent different levels of population substructure. D) Comparison of genetic clustering of samples into two and four groups using the Bayesian clustering program Structure without a location prior. Each column represents an individual, and is divided according to its probability of membership of cluster 1 (orange), 2 (blue), 3 (dark purple) 4 (green), or 5-10 (other colours). 


\section{$\mathbf{A}=$ PeerJ}
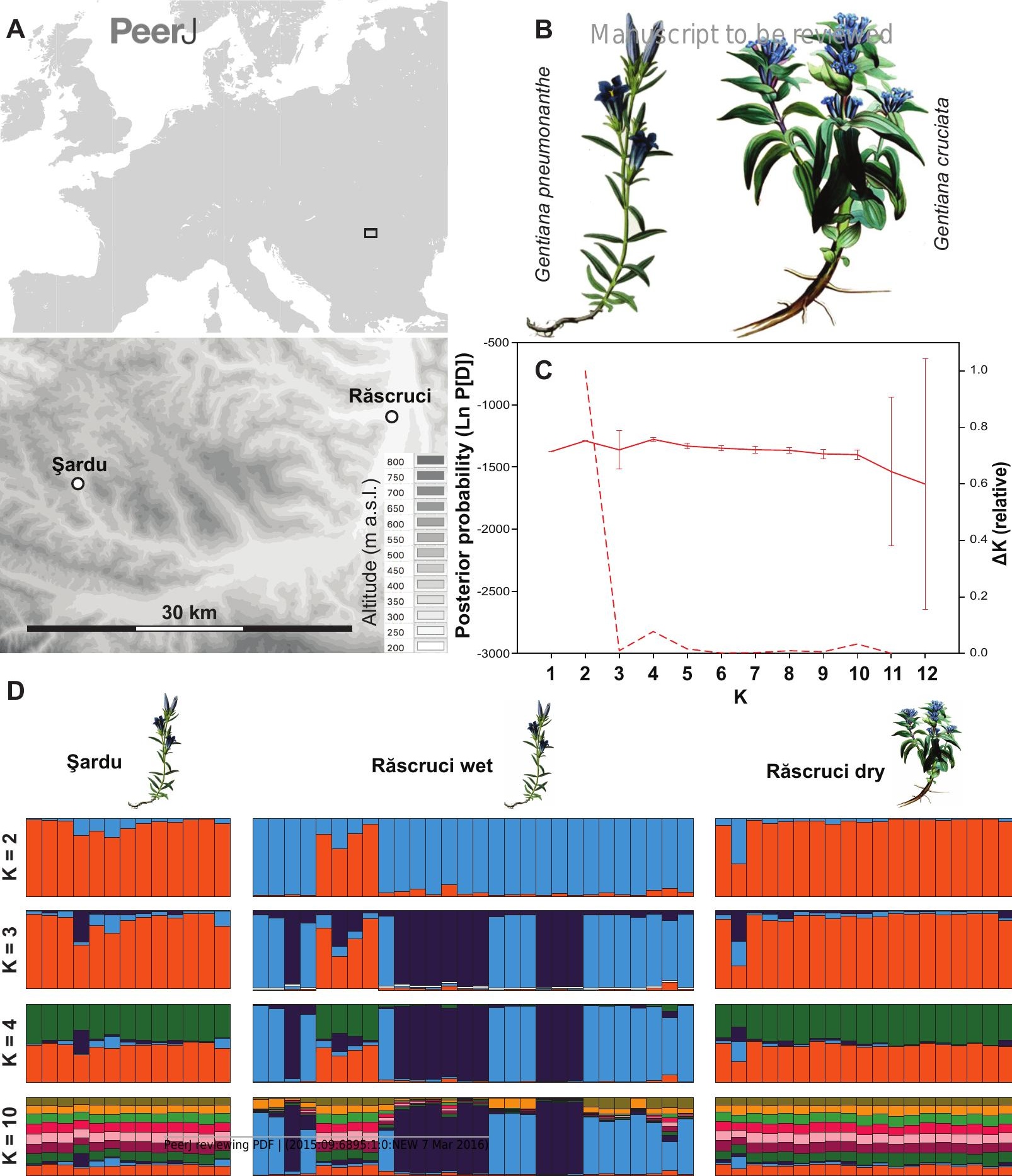

D

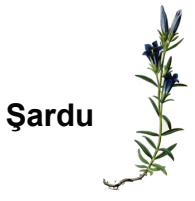


Figure 2 (on next page)

Ordination of samples based on principal coordinate analysis

Each symbol represents an individual, coloured according to its pre-defined population (blue $=$ Răscruci wet, orange $=$ Răscruci dry, purple $=$ Şardu). Coloured lines are convex hulls enclosing all samples from each pre-defined population, while coloured regions are convex hulls enclosing samples collected from the same nest. The single individual (sample DB15) collected from a My. scabrinodis nest at Răscruci dry is shown with a larger symbol. 


\section{Figure 3 (on next page)}

Relatedness and parentage analysis of samples

The pairwise matrix show the estimated Queller \& Goodnight (1989) relatedness of each pair of individuals (excluding those with negative relatedness) above the diagonal, and the probability that each pair are full siblings based on maximum likelihood estimates from Colony (Jones \& Wang, 2010) below the diagonal. Comparisons between samples from the same pre-defined population are shaded according to the same colour scheme as Figure 2 (blue $=$ Răscruci wet, orange $=$ Răscruci dry, purple $=$ Şardu). Individuals sharing the same ant nest are outlined with lines in these same colours, and those sharing the same Myrmica species as host are outlines with black lines. The area and shade of each data point is proportional to the relatedness or probability of being full siblings for that pair of individuals. 


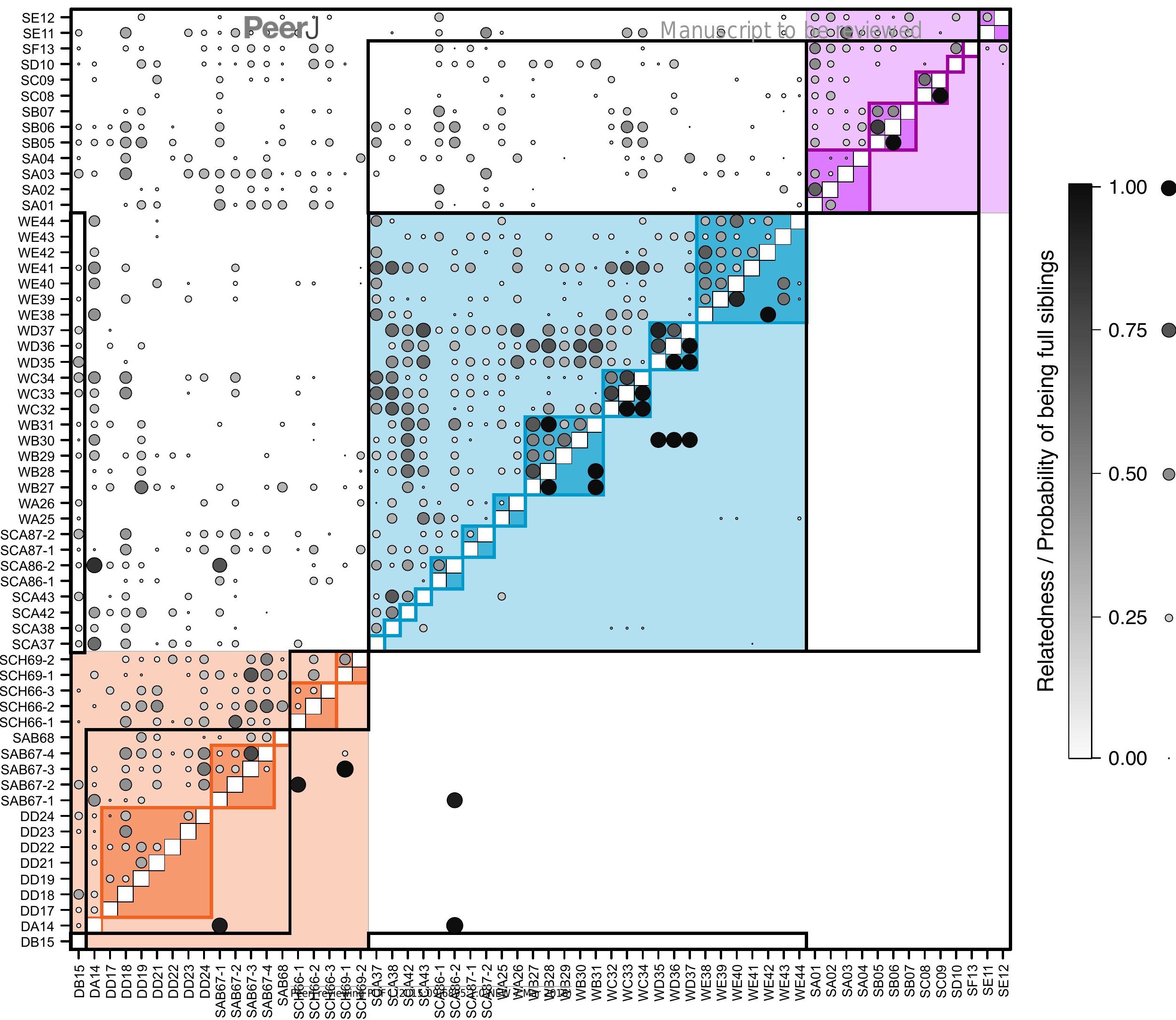

